\title{
KETERKAITAN KONDISI GEOMORFOLOGI DENGAN KARAKTERISTIK AIRTANAH DANGKAL DI KECAMATAN MASARAN KABUPATEN SRAGEN PROPINSI JAWA TENGAH
}

\author{
Oleb : Suwarno
}

\begin{abstract}
In the research area, the rice field lay fallow in dry season because it's lack of water for irrigation, allbough the topography is plain. tbus, it's possible to use ground water for irrigation. Some artesian well were dry in the undulating area.

This research aimed to classify the research area in the landform unit and to investigate the interrelation with the characteristics of shallow groundwater.

The method to make landform unit was supported by topographic map and geological map, and field check. Groundwater characteristics consist of the deptb of groundwater level, coefficient transmisibility, coefficient permeability, discharge of groundwater flow, porosity, the fluctuation of groundwater level, and water quality. The hydrogeomorpholigical map was compiled by landform unit and characteristics of free groundwater.

The research result showed that the geomorphological condition bas interrelated with the characteristics of free groundwater. The interrelation was reflected by landform unit and hydrogemorphological unit. Each of landform unit has different charactersitics, not only quantity but quality as well. the natural levee bas bigh potency of groundwater and the quality is the best.
\end{abstract}

\section{INTISARI}

Di daerah penelitian pada saat musim kemarau laban persawaban dalam keadaan bero (tidak ditanami) karena kekurangan air untuk irigasi, pada hal daerabnya bertopografi datar, sebingga memungkinkan untuk memanfaatkan airtanab sebagai sarana irigasi, sedang di daerab dengan topografi bergelombang banyak sumur gali yang kering. Penelitian ini bertujuan untuk mengklasifikasikan daerab penelitian menjadi satuan bentuk laban dan mencari keterkaitannya dengan karakteristik airtanab dangkal.

Metode yang digunakan yaitu interpretasi foto udara dengan didukung oleh peta topografi dan peta geologi serta cek lapangan, sebingga tersusun peta satuan bentuk laban. Karakteristik airtanab dangkal meliputi kedalaman muka airtanah, koefisien transmisibilitas, koefisien permeabilitas, debit aliran airtanah, po- 
rositas batuan, fluktuasi muka airtanah, dan kualitas airtanab. Dari peta satuan bentuk laban disusun peta bidromorfologi; dengan cara memasukkan data ka. rakteristik airtanab dangkal.

IIasil penelitian ini menunjukkan babva, kondisi geomorfologi mempunyai keterkaitan dengan karakteristik airtanab dangkal yang tercermin pada satuan bentuklaban dan satuan bidromorfologi. Pada setiap satuan bentuklaban mempunyai karakteristik airtanab dangkal yang berbeda-beda baik kualitas maupun kuantitas. Satuan bentuklaban tanggui alam potensi airtanabnya terbesar dan kualitasnya terbaik.

\section{PENDAHULUAN}

\section{Latar Belakang Penelitian}

Kondisi Geomorfologi dan airtanah merupakan bagian dari unsur lingkungan fisik suatu daerah. Lingkungan fisik ini mempunyai arti penting bagi kehidupan manusia selain dari modal dan tenaga (Sutikno, 1971). Oleh karena itu manusia berkecenderungan untuk mengelola lingkungan fisik sccara optimal baik yang ada di permukaan bumi maupun yang ada di bawah permukaan bumi. Untuk dapat mengelola dengan baik maka diperlukan data geomorfologi dan airtanahnya.

Daerah penelitian terletak di Kecamatan Masaran Kabupaten Dati II Sragen Propinsi Jawa Tengah. Daerah ini bertopografi datar hingga bergelombang dan dilewati oleh Sungai Mungkung yang merupakan bawas wilayah bagian timur dan Sungai Bengawan Solo yang merupakan batas wilayah bagian barat. Permasalahan yang sering tumbul adalah pada setiap musim kemarau terdapat lahan persawahan yang bero dikarenakan tidak terdapat air irigasi dan sebagian mengalami kekurangan air untuk keperluan sehari-hari karena sumber airtanah kering.

Belum tersedianya peta geomorfologi seluruh daerah atau data airtanah, padahal untuk themanfaatkan airtanah harus diketahui potensinya. Potensi airtanah dapat diketahui dengan berbagai pendekatan. Salah satu pendekatan yang dapat digunakan adalah pendekatan geomorfologi. Cakupan geomorfologi menurut Karmono Mangunsukardjo (dalam Sutikno, 1990) salah satunya adalah mempelajari hubungan antara bentuklahan dengan unsur bentang alam seperti batuan, struktur geologi, tanah, air, vegetasi, dan penggunaan lahan.

\section{Perumusan masalah}

Berdasarkan uraian di atas dapat dirumuskan permasalahan dalam penelitian ini adalah :

a. Seberapa jauh satuan bentuklahan dapat dijadikan dasar untuk mengetahui karakteristik airtanah dangkal di daerah penelitian;

b. Bagaimanakah hubungan antara parameter geomorfologi terhadap karakteristik airtanah dangkal di daerah penelitian.

\section{Tujuan Penelitian}

Tujuan penelitian ini adalah :

a. mengklasifikasikan daerah penelitian menjadi satuan bentuklahan sebagai dasar untuk mengetahui karakteristik airtanah dangkal; 
b. mengetahui karakteristik airtanah dangkal pada setiap satuan bentuklahan;

c. Mencari hubungan antara parameter geomorfik dengan karakteristik airtanah dangkal, baik secara parametrik maupun menurut satuan bentuklahan.

\section{Landasan Teori}

Dalam penelitian ini landasan teori yang digunakan adalah :

a. Karakteristik airtanah dangkal dipengaruhi oleh berbagai faktor seperti iklim, geologi, geomorfologi, tanah, dan penggunaan lahan. Faktor iklim terutama curah hujan dapat memberikan gambaran tentang keterkaitan airtanahnya. Faktor Geologi dan geomorfologi dapat memberikan gambaran tentang batuan yang menjadi akifer, tipe akifer, karakteristik airtanah dan penggunaan lahannya dapat memberikan gambaran tentang kualitas airtanah.

b. Unit geomorfologi suatu daerah dapat dirinci lagi kedalam satuan bentuklahan, dan setiap satuan bentuklahan mempunyai relief, lithologi dan proses tertentu dan akan mencerminkan karakteristik airtanah dangkal di suatu dacrah. Sctiap satuan bentuklahan dapat dijadikan dasar untuk penentuan satuan hidromorfologi.

c. Karakteristik airtanah dicerminkan oleh besarnya koefisien transmisibilitas, koefisien permeabilitas, debit, porositas batuan, kedalaman muka airtanah dan kualitas airtanah.

d. Peta hidromorfologi disusun berdasarkan pada satuan bentuklahan dengan cara memasukkan data karakteristik airtanah kedalamnya.

\section{Hipotesa}

a. Setiap satuan bentuklahan mempunyai karakteristik airtanah dangkal yang berbeda-beda;

(1) satuan bentuklahan tanggul alam mempunyai karakteristik airtanah yang berbeda dengan satuan bentuklahan dataran kaki volkanik terutama potensinya.

(2) Satuan bentuklahan dataran banjir mempunyai karakteristik airtanah dangkal yang berbeda dengan satuan bentuk lahan kaki volkanik terutama kualitasnya.

b. Secara parametrik antara kondisi geomorfologi dengan karakteristik airtanah dangkal :

(1) lereng mempunyai hubungan erat dengan kedalaman muka airtanah, sehingga semakin besar kelerangannya semakin dalam muka airtanahnya.

(2) material batuan mempunyai hubungan erat dengan kedalaman muka airtanah, batuan volkanik tua, muka airtanahnya lebih dalam bila dibandingkan dengan batuan lainnya di daerah penelitian.

\section{METODE PENELITIAN}

\section{Bahan yang digunakan}

Bahan yang digunakan dalam penelitian ini adalah data curah hujan, data bor, peta geologi, peta topografi, peta tanah, peta penggunaan lahan, foto udara dan sampel airtanah dangkal. 


\section{Alat Yang Digunakan}

Dalam penelitian ini alat yang digunakan adalah :

\section{a. Stereoskop cermin:}

untuk interpretasi foto udara

b. Palu geologi:

untuk memukul/memecahkan batuan guna identifikasi batuan.

c. Pompa:

untuk mengadakan uji pemompaan.

d. Pelampung:

untuk mengukur penurunan dan kenaikan muka airtanah.

e. Kompas Geologi:

untuk menentukan arah lereng dan kemiringan perlapisan batuan.

f. Abney Level: untuk mengukur kemiringan lereng

g. Pita Ukur:

Untuk mengukur kedalaman muka airtanah dan mengukur aspek morfometri bentuklahan.

h. Kamera:

untuk mengambil gambar di lapang. an yang penting yang sesuai dengan penelitian.

i. Alat Laboratorium:

untuk menganalisa sampel air guna mengetahui sifat fisika, kimia dan biologisnya.

\section{Cara Penelitian}

2. Pengumpulan data

Dalam tahap pengumpulan data ini diawali dengan interpretasi foto udara dan mengacu pada peta bahan yang telah ada. Interpretasi foto udara dimaksudkan untuk memperoleh data topografi, bentuklahan, proses, lithologi, dan struktur geologi. Hasil interpretasi foto udara disajikan ke dalam peta bentuklahan sementara dan peta hidromorfologi sementara. Tahap selan. jutnya adalah kerja lapangan yang meliputi pengukuran aspek morfometri dan uji pemompaan dengan metode "Yacob"

\section{b. Pengolaban Data}

Untuk pengolahan data ini menggunakan metode statistik untuk digunakan mencari keterkaitan antara parameter geometrik dengan karakteristik airtanah, menggunakan analisa tabel dan analisa korelasi"Pearson Product Moment" "dengan persamaan sebagai berikut :

$$
\begin{aligned}
& \mathrm{n} \Sigma \mathrm{XY}-\Sigma \mathrm{X} \Sigma \mathrm{Y} \\
& r=\sqrt{\left[\sum x 2 \cdot(\Sigma x) 2\right]\left[n \Sigma y 2 \cdot\left(\sum y\right) 2\right]} \\
& \mathbf{r}=\text { nilai korelasi } \\
& \mathrm{n}=\text { jumlah data } \\
& \mathbf{x}=\text { parameter geometrik (besar sudut, }
\end{aligned}
$$

(Sumber : Anton Dayan, 1986)

untuk pengolahan data, kualitas airtanahnya dengan dibuat diagram stiff.

\section{c. Analisa Data}

Data karakteristik airtanah dangkal tersebut dimasukkan atau diplot pada peta satuan bentuklahan atau peta satuan hidromorfologi. Untuk mengetahui keterkaitan antara kondisi geomorfologi dengan karakteristik airtanah dangkal dibuat peta satuan hidromorfologi akhir. Analisa data dilakukan dengan analisis parametrik dan analisis terpadu. 


\section{HASIL PENELITIAN}

Di dacrah penclitian terdapat lima satuan bentuklahan yaitu : tanggul alam, dataran banjir, dataran fluvial yolkanik, dataran kaki volkanik dan kaki, volkanik. Untuk mencari kctcrkaitan antara kondisi geomorfologis yang tercermin dalam setiap satuan bentuklahan dengan karakteristik airtanah dangkal digunakan dua cara yaitu dengan analisa parametrik dan analisa terpadu. Dalam analisa parametrik menggunakan metode statistik yaitu dengan korelasi Pearson Product Moment, sedang dalam analisa terpadu menggunakan metode diskriptif yaitu menguraikan karakteristik di setiap satuan bentuklahan beserta karakteristik airtanah dangkal.

\section{Keterkaitan secara parametrik}

Analisa secara parametrik ini didasarkan pada aspek mirfometri pada setiap satuan bentuk lahan dan dalam hal ini yang dimaksud adalah aspek kelerengan. Analisa ini dilakukan untuk mengetahui keterkaitan antara aspek kelerengan dengan karakteristik air tanah dangkal. Karakteristik air tanah dangkal untuk analisa ini adalah kedalaman muka air tanah dan besarnya daya hantar listrik.

Besarnya sudut lereng dan bentuk lereng dimiliki dalam analisa ini karena besarnya sudut lereng berpengaruh terhadap besarnya air hujan yang meresap ke dalam tanah. bentuk lahan dengan sudut lereng besar, maka kecepatan aliran permukaannya tinggi sehingga kesempatan air untuk meresap ke tanah kecil dan sebaliknya bila sudut ierengnya kecil maka kecepatan aliran permukaannya rendah maka hal ini memberikan kesempatan air permu. kaan untuk meresap ke tanah semakin besar. Dengan demikian besarnya sudut lereng berpengaruh terhadap besarnya air permukaan yang ke tanah hal ini akan berpengaruh terhadap kedalaman muka air tanah. Bentuk lereng cembung, lurus dan cekung berpengaruh terhadap kesempata air untuk meresap ke tanah (infiltrasi), pada lereng yang cekung merupakan tempat berkumpulannya air permukaan maka pada bentuk lereng cekung terjadi pengendapan unsur-unsur kimia semakin besar bila dibandingkan dengan bentuk lereng cembung yang keberadaan air permukaan relatif sebantar dan pada bentuk lereng lurus air akan mengalir terus sehingga kesempatan untuk mengendapkan unsur kimia kecil. Karena besarnya daya hantar listrik tersebut juga dipengaruhi oleh kandungan ion atau unsur kimianya, maka terdapat keterkaitan antara bentuk lereng dengan besarnya daya hantar listrik. Oleh karena itu untuk mencari besarnya keterkaitan antar parameter tersebut digunakan persamaan korelasi persons product moment. 
Tabel : 1 Hubungan lereng dengan kedalaman muka air tanah

\begin{tabular}{|c|c|c|c|c|c|c|c|}
\hline \multirow{2}{*}{ No } & \multicolumn{2}{|c|}{ Lereng ( $\mathbf{x})$} & \multirow{2}{*}{$\begin{array}{c}\text { Kedalaman (m) } \\
\text { (Y) }\end{array}$} & \multirow{2}{*}{ No } & \multicolumn{2}{|c|}{ Lereng ( $x$ ) } & \multirow{2}{*}{$\begin{array}{c}\text { Kedalaman (m) } \\
\text { (Y) }\end{array}$} \\
\hline & Besar $\%$ & Bentuk & & & Besar $\%$ & Bentuk & \\
\hline 1 & 1 & Lurus & 1,05 & 19 & $3 \cdot 8$ & Lurus & 1,2 \\
\hline 2 & 1 & $"$ & 1,2 & 20 & $"$ & $"$ & 0,8 \\
\hline 3 & $"$ & $"$ & 0,8 & 21 & $"$ & $"$. & 7,5 \\
\hline 4 & $"$ & $"$ & 0,5 & 22 & $"$ & $"$ & 10,5 \\
\hline 5 & $"$ & $"$ & 1,15 & 23 & $"$ & $"$ & 3,55 \\
\hline 6 & 2 & Cekung & 1,5 & 24 & $"$ & $"$ & 8,7 \\
\hline 7 & $"$ & " & 4,0 & 25 & $"$ & & 1,35 \\
\hline 8 & $"$ & $"$ & 4,55 & 26 & $"$ & $*$ & 6,0 \\
\hline 9 & 0.2 & $"$ & 2,9 & 27 & $8 \cdot 16$ & Cembung & 9,5 \\
\hline 10 & $"$ & $"$ & 0,5 & 28 & " & " & 3,2 \\
\hline 11 & $"$ & $"$ & 2,9 & 29 & $"$ & $"$ & 4,0 \\
\hline 12 & $"$ & " & 1,2 & 30 & $"$ & $"$ & 12,6 \\
\hline 13 & $3 \cdot 8$ & Lurus & 4,0 & 31 & $"$ & $"$ & 8,4 \\
\hline 14 & " & " & 4,9 & 32 & $"$ & $"$ & 21,0 \\
\hline 15 & $"$ & $"$ & 8,3 & 33 & $"$ & $"$ & 12,4 \\
\hline 16 & $"$ & $"$. & 4,55 & 34 & $"$ & $"$ & 0,65 \\
\hline 17 & $"$ & $n$ & 4,6 & 35 & $"$ & $"$ & 30,0 \\
\hline 18 & $"$ & $"$ & 2,2 & & & & \\
\hline
\end{tabular}

Sumber : Data Primer

Dari perhitungan Tabel 1. hubungan antara besarnya sudut lereng dengan kedalaman muka air tanah diperoleh nilai korelasi $(r)$ positip 0,6 oleh karena itu dapat diartikan bahwa ada keterkaitan secara positif antara besar. nya sudut lereng dengan kedalaman muka air tanah. Jadi semakin tinggi sudut lerengnya maka semakin dalam muka air tanahnya dan atau sebaliknya. Untuk mencari hubungan antara ben. tuk lereng dengan kedalaman muka air tanah, maka bentuk lereng cembung diberi skor dua dan bentuk lereng lurus diberi skor satu. Oleh karena itu dari perhitungan Tabel 1 nilai korelasinya diperoleh nilai korelasinya sebagai (r) positip 0,06, maka dapat diartikan ada keterkaitan yang positip antara bentuk lereng dengan kedalaman muka air tanah. Tabel 2 menyajikan hubungan antara bentuk lereng dengan besarnya daya hantar listrik. 
Tabel 2. Hubungan Antara Bentuk Lereng Dengan\ Daya Hantar Listrik

\begin{tabular}{|c|l|c|c|}
\hline No & Bentuk lereng & Skor & $\begin{array}{c}\text { Daya Hantar Listrik } \\
\text { (Mikro mhos/cm) }\end{array}$ \\
\hline 1 & Lurus & 1 & 831 \\
2 & Cekung & 3 & 1300 \\
3 & Cekung & 3 & 3872 \\
4 & Cembung & 2 & 1521 \\
5 & Cembung & 2 & 890 \\
6 & Lurus & 1 & 1051 \\
\hline
\end{tabular}

Sumber : Data Primer

Berdasarkan hasil perhitungan Tabel 2, tersebut diperoleh nilai korelasi (r) sebesar positip 0.27 , hal ini dapat diartikan bahwa terdapat hubungan yang positip antara bentuk lereng dengan besarnya daya hantar listrik, dengan tingkat hubungan yang rendah.

Nilai $r$ positip yang kecil tersebut mempunyai hubungan yang lemah. Hubungan yang lemah mungkin disebabkan olch jumlah data kurang dan banyak faktor lainnya yang berpengaruh terhadap daya hantar listrik.

\section{Keterkaitan Secara Terpadu}

Analisa terpadu yang dimaksud adalah menggunakan satuan bentuk lahan sebagai satuan evaluasi. Dalam hal ini satuan bentuk lahan digunakan untuk mencari keterkaitann antara kondisi geomorfologi dengan karakteristik air tanah dangkal di daerah penelitian. Oleh karena dalam tulisan ini yang digunakan untuk mengklasifikasikan satuan bentuk lahan didasarkan pada litologi. Relief dan proses maka di setiap satuan bentuk lahan akan dicirikan oleh ketiga hal tersebut. Karakteristik air tanah dangkal dicirikan oleh besarnya porositas batuan. Fluktuasi, kedalam muka air tanah, koefisien transmisibilitas, koefisien permeabilitas, debit aliran air tanah dan kualitas air tanahnya.

\subsection{Tanggul alam dengan karak- teristik air tanab dangkal}

Pada satuan bentuk lahan ini proses yang terjadi adalah sedimentasi dan erosi lembah. Mempunyai lereng $2 \%$ bertopografi datar dan material batuannya terdiri dari pasir lepas.

Air tanah pada satuan bentuk lahan ini sangat dipengaruhi oleh fluktuasi dari permukaan air Bengawan Solo. Dari hasil wawancara diperoleh keterangan bahwa sumur-sumurnya kedalaman dari muka air tanah terpengaruh langsung oleh aliran Bengawan Solo. Apabila musim penghujan aliran Bengawan Solo besar sehingga muka air tanah dangkal. Sedang pada musim kemarau aliran Bengawan Solo kecil maka muka air tanahnya dalam terkadang kering maka banyak sumur dibuat dengan kedalaman melebihi dalamnya 
Bengawan Solo supaya sumurnya tidak kering di musim kemarau. Hal ini menunjukkan bahwa air tanah pada satuan bentuk lahan ini fluktuasinya sangat tergantung pada besar kecilnya aliran Bengawan Solo. Porositas dari akifernya adalah antara $30-40 \%$ fluktuasinya lebih dari $3 \mathrm{~m}$. Ini hasil dari informasi yang memiliki sumur pada lokasi uji pemompaan. Hasil dari uji pemompaan diperoleh nilai.

$\begin{array}{ll}\text { Kocfisien transmisiblitas } & : 1898,6 \mathrm{~m}^{2} / \text { hari } \\ \text { Koefisien permeabilitas } & : 632,87 \mathrm{~m} / \mathrm{hari} \\ \text { Debit aliran air tanah } & : 41769,42 \mathrm{~m} 3 / \text { hari }\end{array}$

Rata-rata kedalaman muka air tanahnya pada saat dilakukan observasi anatar 0,5 - 4,5 meter. Gradien hidroInya $4.10^{-3}$. Kualitas air tanahnya adalah baik.

\section{Dataran banjir dengan karak- teristik air tanab dangkal}

Pada satuan bentuk lahan ini proses yang terjadi adalah sedimentasi, mempunyai lereng $1 \%$, bertopografi datar, dan material batuannya terdiri dari pasir, lempung dan lanau.

Air tanah pada satuan bentuk lahan ini juga terpengaruh oleh aliran dari sungai di sekitarnya, maka muka air tamah sctclah tergenang olch air sungai permukaan air tanahnya dangkal. Ratarata kedalaman air tanahnya pada saat observasi antara 0,5 hingga 1,8 $\mathrm{m}$ kondisi air tanah sangat tergantung oleh air sungai, biasanya setelah banjir air tanahnya keruh dan kekeruhan tersebut semakin berkurang setelah air sungai surut kembali. Untuk mengatasi hal tersebut selarang ini banyak penduduk yang mengganti sumur galinya dengan sumur pantek. Porositas dari akifernya antara $1 \cdot 20 \%$. Fluktuasi dari air tanah yang diperoleh dari wawancara penduduk berkisar anatar 2 hingga $3 \mathrm{~m}$. Hasil dari uji pemompaan diperoleh nilai.

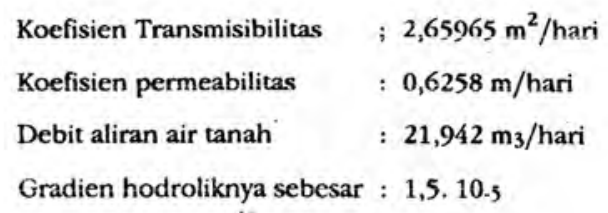

Kualitas dari air tanahnya adalah kurang baik karena air tanahnya mempunyai nilai kekeruhan tinggi yaitu 9,6 FTU ini melebihi batas maximum sebesar 5 FTU. Kekeruhan ini disebabkan oleh banyaknya unsur-unsur kimia yang tidak dapat larut ke dalam air tanah tersebut. Banyaknya unsur kimia tersebut diakibatkan oleh sering tergenangnya daerah tersebut akibat dari seringnya banjir.

\subsection{Dataran fluvial volkanik dengan karekteristik air tanab.}

Pada satuan bentuk lahan ini proses yang terjadi adalah sedimentasi pada alur-alur sungai, mempunyai lereng antara $0 \cdot 2 \%$, beropografi datar dan material batuannya terdiri dari batu pasir.

Kondisi air tanahnya adalah sebagai berikut permukaan air tanahnya relatif dangkal pada saat observasi kedalam muka air tanahnya berkisar antara 0,5 sampai dengand 2,5 m. Fluktuasi dari muka air tanahnya 1,5 hingga $2,5 \mathrm{~m}$. Porositas dari akifarnya berkisar anatar $10-20 \%$.

Hasil dari uji pemompaan diperoleh hasil 


$\begin{array}{ll}\text { Koefisien transmisibilitas } & : 593,31 \mathrm{~m}^{2} / \text { hari } \\ \text { Koefisien permeabilitas } & : 134,54 \mathrm{~m} / \text { hari } \\ \text { Debit aliran air tanah } & : 8321,33 \mathrm{~m} / \text { hari } \\ \text { Gradien Hidroliknya sebesar } & : 3,3.10-3\end{array}$

Gradien hidroliknya sebesar : 3,3.10-3. Kualitas air tanahnya adalah jelek karena kandungan unsur kimianya telah melebihi batas maksimum yang diperbolehkan. Kandungan $\mathrm{Ca}$ pada lokasi ini adalah $393 \mathrm{ppm}$ pada hal batas maksimum yang diperbolehkan sebesar 200 ppm kandungan C1 nya adalah $721 \mathrm{ppm}$ ini melebihi batas maksimum yang diperbolehkan 700 ppm, sedangkan daya hantar listriknya cukup tinggi sebesar 3872 mikro mhos $/ \mathrm{cm}$. Besarnya daya hantar listrik tersebut disebabkan oleh tingginya kandungan ion-ion dalam air tanah dan atau adanya jebakan air asin ini dapat diperkirakan pada lokasi ini dulunya merupakan laut dangkal yang karena pada lokasi ini terdapat lapisan lempung yang cukup tebal oleh penduduk setempat diperkirakan tebalnya lebih dari satu meter.

\subsection{Dataran kaki vulkanik dengan karakteristik air tanab dangkal}

Pada satuan bentuk lahan ini proses erosi permukaan, mempunyai lereng $3-8 \%$, bertopografi landai dan material batuannya terdiri dari batu pasir.

Air tanah satuan bentuk lahan ini mempunyai kedalaman anatar 3,5 hingga $12 \mathrm{~m}$. Fluktuasi air tanahnya berkisar anatar 1 hingga $2 \mathrm{~m}$. Porositas akifernya anatar $10-20 \%$.
Hasil uji pemompaan diperoleh nilai

$$
\begin{array}{ll}
\text { Koefisien transmisibilitas } & : 1,534 \mathrm{~m}^{2} / \text { hari } \\
\text { Koefisien permeabilitas } & : 0,6817 \mathrm{~m} / \mathrm{hari} \\
\text { Debit aliran air tanah } & : 29,143 \mathrm{~m}_{3} / \text { hari } \\
\text { Gradien Hidroliknya sebesar } & : 4,10-3
\end{array}
$$

Kualitas air tanahnya adalah masuk dalam klasifikasi baik untuk air minum karena kandungan unsur kimianya belum melebihi persyaratan standard air minum dari Departemen Kesehatan Republik Indonesia.

\subsection{Kaki vulkanik dengan karak- teristik air tanab dangkal}

Pada satuan bentuk lahan ini proses yang terjadi adalah proses erosi permukaan, erosi alur, erosi parit dan proses pelapukan, mempunyai lereng antara $8 \cdot 16 \%$ bertopografi bergelombang, material batuannya terdiri dari pasir, kerakal dan bongkah.

Oleh karena adanya variasi lereng maka mempunyai variasi kedalaman muka air tanah antara 0,65 hingga 30 m. Fluktuasi muka air tanahnya yang diperoleh dari penduduk setempat adalah antara 1 hingga $2 \mathrm{~m}$. Porositas akifernya antara $20 \cdot 35 \%$. Sebagian besar pada musim kemarau banyak sumur yang kering, maka penduduk tersebut kekurangan air untuk kebutuhan sehari-hari. Hasil dari uji pemompaan diperoleh nilai :

\footnotetext{
Koefisien transmisibilitas $\quad: 2259,04 \mathrm{~m}^{2} /$ hari Koefisien permeabilitas $\quad: 451,808 \mathrm{~m} / \mathrm{hari}$ Debit aliran air tanah $\quad$ : $5085,84 \mathrm{~m}_{3} /$ hari Gradien Hidroliknya sebesar : 7,5.10.3
}

Kualitas air tanahnya dapat diklasifikasikan berkualitas baik untuk air minum. 


\section{KESIMPULAN DAN SARAN}

\section{KESIMPULAN}

Bcrlasarkan urairan tersebut di acs, maka dapat diambil kesimpulan sperti tersebut dibawah ini

1. Unit geomorfologi daerah penelitian dapat dibagi dalam beberapa satuan bentuk lahan yaitu

(12) Tanggul alam

(6) Dataran banjir

(c) Dataran fluvial volkanik

If) Dararan kaki volkanik

(c) Kaki volkanik

2 Froses geomorfologi yang berlangsung terus adalah proses, pelapukan, erosi dan sedimentasi.

3. Setiap satuan bentuk lahan mempunyai potensi dan karakteristik air tamah dangkal yang berbeda-beda, satuan bentuk lahan tanggul alam mempunyai kualitas terbaik dan kuantitas terbesar.

4. Ada keterikatan antara kondisi geo- morfologis dengan karakteristik air tanah dangkal baik secara parame. trik maupun secara terpadu, secara parametrik besarnya sudut lereng dan bentuk lereng mempunyai keterkaitan dengan kedalaman air ta. nah, bentuk lereng berpengaruh terhadap besarnya daya hantar listrik, sedangkan secara terpadu menunjukkan adanya perbedaan disetiap satuan bentuk lahan maka mempunyai karakteristik yang berbeda pula.

5. Untuk mempelajari air tanah salah satunya dapat menggunakan pendekatan geomorfologi, yang dalam tulisan ini adalah mengkaitkan antara satuan bentuk lahan dengan keling. kungan yang lain yaitu air tanah.

\section{SARAN}

Apabila Pemerintah akan mengembangkan air tanah di daerah penelitian sebaiknya pada satuan bentuk lahan tanggul alam karena dari potensi maupun mutu akan tercukupi atau pada kaki volkanik dengan alasan untuk membantu meringankan penduduk supaya tidak kekurangan air lagi. 


\section{DAFTAR PUSTAKA}

Anton, Dayan, 1986 Pengantar Metode Stastistik, jilid I Jakarta : LP3ES.

Bemmelen RW. VAN, 1949, The Geologi of Indonesia vol I, The Hague : Goverment Printing office.

Bouwer, Herman, 1978, Groundwater Hidrology, New York : McGrarw Hill Book Company.

Desunettes, JR. 1977, Catalogue of Landfrom for Indonesia land Capability Appraisal, Project Food and Agriculture Organitation.

Gamma Epsilon, pt. 1989, Detail Design Perbaikan Anak-anak Sungai Bengawan Solo, penyelidikan Geologi dan Mekanika Tanah.

Krussemen, G.P. and De Ridder, N.A. 1970, Analisis and Evaluation of pumping test Data, Nederland; Internasional Institute For Land Reclamasion and Improvement, Wegeningen.

Soetikno, 1971, Kondisi Air tanah Dari Daerah Aliran kall Jati dan kali Mlinjon kecamatan karangan kabupaten Trenggalek, Yogyakarta Skripsi Doktoral II Fakultas Geografi Universitas Gadjah Mada.

Soetikno, 1989, Kajian Bentuk lahan untuk Pemintakatan Sistem Penyediaan Air Bersih di DAS serang Kulon Progo, Yogyakarta : Fakultas Geografi Universitas Gadjah Mada.

Soetikno, 1990, Geomorfologi Perannya dalam Geografi Fisik dan Terapannya dalam penelitian, Makalah Seminar di Fakultas Geografi UMS. 


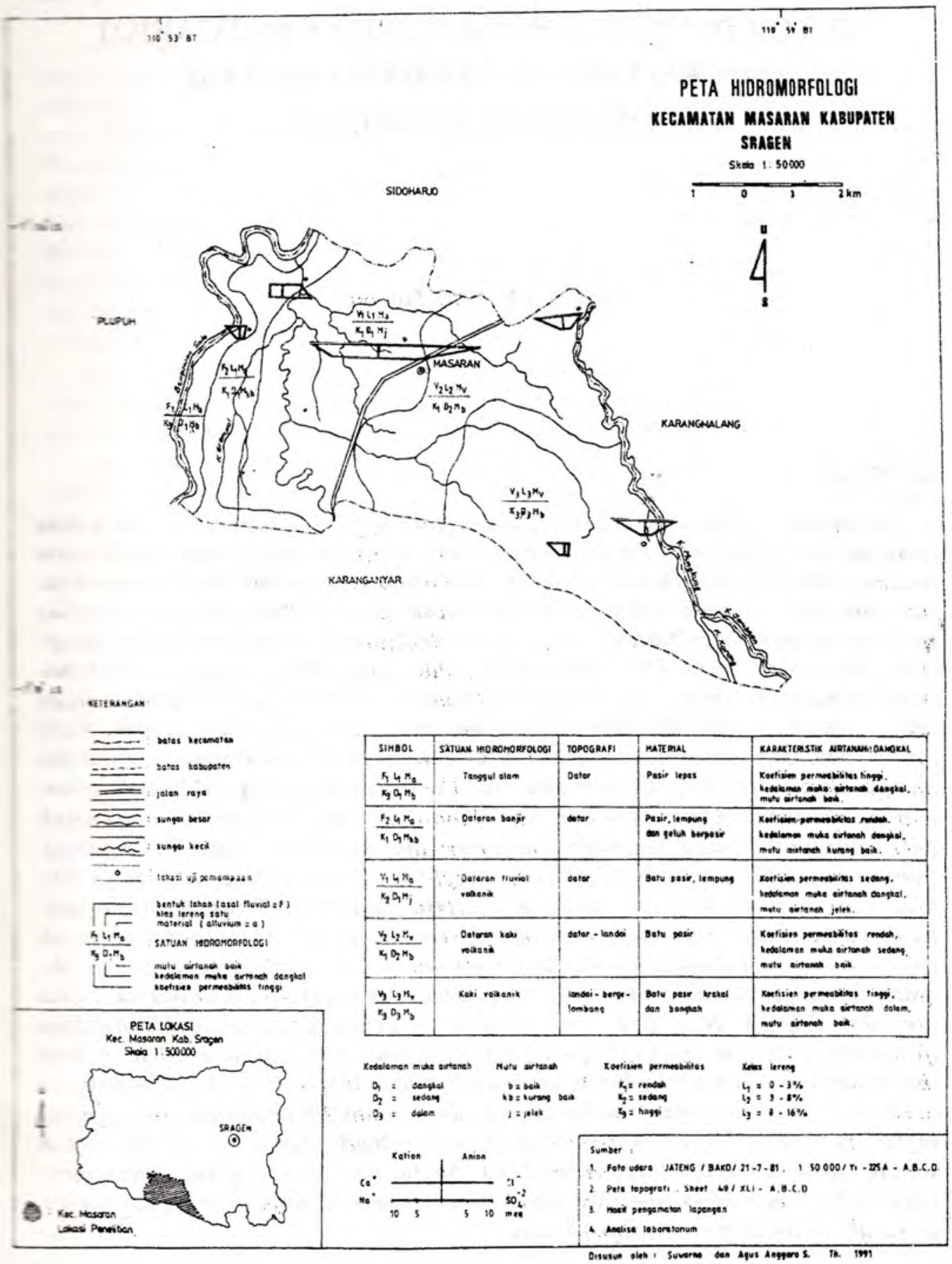

- Forum Geografi No. 13 Th. VII/Desember 1993 